\title{
Strain-Dependent Variation in Vascular Responses to Nitric Oxide in the Isolated Murine Heart
}

\author{
Jennifer K. Bendall, Christophe Heymes, Timothy J. F. Wright, \\ Stephen Wheatcroft, David J. Grieve, Ajay M. Shah and Alison C. Cave \\ Department of Cardiology, Guy's King's and St Thomas' School of Medicine, King's College London, \\ Bessemer Road, London SE5 9PJ
}

(Received 28 December 2001, accepted for publication 26 June 2002)

\begin{abstract}
J. K. Bendall, C. Heymes, T. J. F. Wright, S. Wheatcroft, D. J. Grieve, A. M. Shah and A. C. Cave. Strain-Dependent Variation in Vascular Responses to Nitric Oxide in the Isolated Murine Heart. Journal of Molecular and Cellular Cardiology (2002) 34, 1325-1333. Numerous studies in the literature have employed gene-modified mice to investigate vascular function. However, only very limited information exists on baseline murine vascular physiology or on potential variations between different strains. We therefore compared coronary and aortic vascular responses to endothelium-derived vasodilators and exogenous nitric oxide (NO) in three commonly used mouse strains and correlated these data with expression of eNOS, NADPH oxidase subunits, gp91 ${ }^{\text {phox }}$ and p6 $7^{\text {phox }}$, and superoxide production. Isolated perfused hearts from MF1, 129sv and C57BL/6J mice were subjected to: (a) increasing doses of bradykinin, acetylcholine and sodium nitroprusside, and (b) bolus doses of adenosine and the NO synthase inhibitor, $\mathrm{N}^{\mathrm{G}}$-monomethyl-L-arginine. Vascular responses of thoracic aortic rings were assessed for comparison. Expression of eNOS and NADPH oxidase subunits was assessed by immunoblotting, and superoxide production by lucigenin-enhanced chemiluminescence. Coronary vasodilator responses to bradykinin, acetylcholine and sodium nitroprusside were significantly attenuated in MF1 compared with C57BL/6J and 129 sv hearts. Similarly, aortic relaxation to acetylcholine was significantly impaired in MF1 aortic rings compared with in C57BL/6J aortae; these differences were reversed by Tiron. $\mathrm{N}^{\mathrm{G}}$-monomethyl-L-arginine induced significantly less vasoconstriction in MF1 and 129sv hearts compared with C57BL/6J. No differences in aortic relaxation to A23187 or sodium nitroprusside were observed. Cardiac and aortic superoxide production and cardiac expression of $\mathrm{p} 67^{\text {phox }}$ and gp9 $1^{\text {phox }}$ were significantly greater in MF1 mice compared with the other strains. There is significant strain-dependent variation in coronary and aortic vascular responsiveness in mice, which may reflect differences in the balance between NO and superoxide generation. (c) 2002 Published by Elsevier Science Ltd.
\end{abstract}

Key Words: Nitric oxide; Superoxide; Coronary circulation; Mouse; Vasodilatation; Strain; Aorta.

\section{Introduction}

Recent progress in the ability to manipulate the mammalian genome has led to the proliferation of genetically altered models of disease. As such, genetically modified mice are increasing being used as experimental models of cardiovascular disease. A major strength of this approach is that it uses a precise genetic alteration to investigate complex regulatory processes within the cardiovascular system. However, the molecular techniques requisite for generating such animals developed more rapidly

Please address all correspondence to: Dr Alison C. Cave, Department of Cardiology, GKT School of Medicine, King's Denmark Hill Campus, Bessemer Road, London, SE5 9PJ, UK. Tel: +44(0)20 7346 3024; Fax: +44 (0)20 7346 4771; E-mail: alison.cave@kcl.ac.uk Abbreviations: NO, nitric oxide; (e)NOS, (endothelial) nitric oxide synthase; $\mathrm{O}_{2}^{-}$, superoxide anion; KHB, Krebs-Henseleit buffer; CPP, coronary perfusion pressure; LV, left ventricle; ACh, acetylcholine; SNP, sodium nitroprusside; L-NMMA, $\mathrm{N}^{\mathrm{G}}$-monomethyl-L-arginine; $\mathrm{PE}$, phenylephrine; tiron, 4,5-dihydroxy-1,3-benzene-disulfonic acid disodium; L-NAME, $\mathrm{N}_{\omega}$-nitro-L-arginine methyl ester hydrochloride; DPI, diphenyleneiodium chloride; EDHF, endothelium-derived hyperpolarising factor(s). 
than the methods for studying physiological phenotype. ${ }^{1}$ Therefore, only very limited information exists on baseline murine vascular physiology or on potential variations between different murine strains.

Numerous studies in the literature have employed gene-modified mice to investigate vascular, and more specifically, endothelial function. ${ }^{2-4}$ For example, in contrast to pharmacological modulation via $\mathrm{N}^{\mathrm{G}}$-monomethyl-L-arginine, this approach allows the selective inhibition of single isoforms of nitric oxide $_{1}$ synthase (NOS) to be studied. ${ }^{5-6}$ Knowledge of inherent variations in vascular physiology between different murine strains is therefore essential for accurate data interpretation. Thus, the aim of this study was to assess normal coronary vascular responses to endothelium-dependent vasoactive agonists and exogenous $\mathrm{NO}$ in the isolated, perfused heart of three different mouse strains. Vascular responses in aortic rings were studied for comparison. Only one previous study has examined coronary vascular responses in the whole mouse heart $^{7}$ although vascular responsiveness to endothelium-dependent and -independent agonists has been studied in mouse aortic rings. ${ }^{3,4,8,9}$ None of these studies, however, compared vascular responsiveness between different mouse strains. We studied two inbred strains commonly used for the creation of genetically altered mice in vascular studies, namely $\mathrm{C} 57 \mathrm{BL} / 6 \mathrm{~J}^{10-11}$ and $129 \mathrm{sv}$ mice, ${ }^{12-13}$ and one outbred strain, the MF1 mouse. Differences in coronary and aortic vascular responses were correlated with differences in (a) expression of endothelial nitric oxide synthase (eNOS), (b) expression of subunits of the major vascular superoxide $\left(\mathrm{O}_{2}^{-}\right)$-generating complex, NADPH oxidase, and (c) NADPH-dependent $\mathrm{O}_{2}^{-}$production.

\section{Methods}

All procedures were performed in accordance with the Guidance on the Operation of Animals (Scientific Procedures) Act, 1986 (Her Majesty's Stationery Office, London, UK).

\section{Isolated langendorff-perfused hearts}

Adult male C57BL/6J, 129sv and MF1 mice ( $n \geq 6$ per group; 8-10 weeks old; Harlan, UK) were anaesthetised (pentobarbital sodium, $0.1 \mathrm{ml} / 100 \mathrm{~g}$ ) and heparinised (heparin sodium, $100 \mathrm{IU} / 100 \mathrm{~g}$ ) by intraperitoneal injection. Hearts were rapidly excised, cannulated via the aorta, and perfused in non-recirculating Langendorff mode at constant flow with Krebs-Henseleit buffer (KHB) containing (in $\mathrm{mmol} / \mathrm{L}$ ) $\mathrm{NaCl} 116, \mathrm{KCl} 4.6, \mathrm{MgSO}_{4} 1.1$, $\mathrm{NaHCO}_{3} 24.9, \mathrm{CaCl}_{2} 2.5, \mathrm{KH}_{2} \mathrm{PO}_{4}$ 1.2, glucose 10 , and EDTA 0.5 equilibrated with $95 \% \mathrm{O}_{2}$ and $5 \%$ $\mathrm{CO}_{2}\left(\mathrm{pH} 7.4,37^{\circ} \mathrm{C}\right)$. During a 20 -min equilibration period, coronary flow was adjusted to achieve a coronary perfusion pressure (CPP) of $60 \pm 5 \mathrm{mmHg}$ as used previously. ${ }^{7}$ A CPP of $60 \mathrm{mmHg}$ was found to produce optimal vasodilator responses and preliminary experiments demonstrated that left ventricular (LV) function was normal at this level. CPP was measured via a pressure transducer and data recorded on a MacLab/8 s system (ADI, Australia). A LV balloon was not used as, in preliminary experiments, it was found to impair vasodilator responses in a significant proportion of animals from each strain thereby introducing additional variability and confounding interpretation of the data.

Bolus doses $(10 \mu \mathrm{l})$ of the endothelium-dependent vasoactive agents, bradykinin $(1 \mathrm{nmol} / \mathrm{L}-100 \mu \mathrm{mol} / \mathrm{L})$ and acetylcholine (ACh, $1 \mathrm{nmol} / \mathrm{L}-10 \mu \mathrm{mol} / \mathrm{L}$ ), the endothelium-independent NO agonist, sodium nitroprusside (SNP, $10 \mathrm{nmol} / \mathrm{L}-1 \mathrm{mmol} / \mathrm{L}$ ), and adenosine $(1 \mathrm{mmol} / \mathrm{L})$ were injected just above the aortic cannula into the coronary flow $(\sim 1 \%$ of the flow causing no change in $\mathrm{CPP}$ ), with sufficient time allowed between agents to allow recovery of basal CPP. Basal production of NO was estimated as the maximal vasoconstrictor response to $\mathrm{N}^{\mathrm{G}}$ monomethyl-L-arginine (L-NMMA, $0.1 \mathrm{mmol} / \mathrm{L}$ ).

\section{Isolated aortic rings}

To assess vascular relaxation independently of confounding factors such as coronary vascular resistance and coronary flow, thoracic aortae were studied from $\mathrm{C} 57 \mathrm{BL} / 6 \mathrm{~J}$ and MF1 mice. Aortae were excised and placed in ice-cold KHB, cleaned of excess adventitial tissue, and cut into $5 \mathrm{~mm}$ ring segments. Care was taken not to damage the endothelium. Aortic segments were suspended in individual organ chambers filled with KHB $(10 \mathrm{ml})$, continually gassed with $95 \% \mathrm{O}_{2}$ and $5 \% \mathrm{CO}_{2}$ and maintained at $37^{\circ} \mathrm{C}$. Tension was recorded with a linear force transducer. The resting tension of the rings was set to $3.0 \mathrm{~g}$. After $40 \mathrm{~min}$ equilibration, cumulative dose-response curves to phenylephrine (PE) were performed $(1 \mathrm{nmol} / \mathrm{L}-3 \mu \mathrm{mol} / \mathrm{L})$ and the concentration of PE required to produce $70 \%$ of the maximal contraction used. After a stable contraction plateau was reached, cumulative doseresponse curves to ACh $(3 \mathrm{nmol} / \mathrm{L}-3 \mu \mathrm{mol} / \mathrm{L})$, the calcium ionophore A23187 ( $1 \mathrm{nmol} / \mathrm{L}-0.3 \mu \mathrm{mol} / \mathrm{L})$ 
and SNP $(1 \mathrm{nmol} / \mathrm{L}-0.3 \mu \mathrm{mol} / \mathrm{L})$ were performed. Experiments were also conducted to assess AChinduced relaxation in the presence of the $\mathrm{O}_{2}^{-}$scavenger, Tiron $(5 \mathrm{mmol} / \mathrm{L})$. Relaxation is expressed as a percentage of the $70 \%$ contraction to PE.

\section{Western analyses}

LV tissue from C57BL/6J, 129sv and MF1 mice was excised, snap frozen, and stored at $-80^{\circ} \mathrm{C}$. Tissues were homogenized in buffer containing (in mmol/L) Tris 50 (pH 7.4), NaCl 100, NaF 50, NaEDTA 5, $\beta$-glycerophosphate 40 , and sodium orthovanadate 0.2. Homogenates were centrifuged to remove insoluble material, and protein concentrations assayed using the Bradford technique. ${ }^{14}$ Forty $\mu \mathrm{g}$ protein was loaded onto $10-20 \%$ SDS polyacrylamide gels, electrophoresed, and transferred to nitrocellulose membranes (Amersham, UK). For eNOS expression, a 1:2500 dilution of primary mouse anti-eNOS monoclonal antibody (Transduction Laboratories, UK) was used. Monoclonal antibodies $(1: 1000)$ against gp91 ${ }^{\text {phox }}$ (donated by Dr M. Quinn) and p67 $7^{\text {phox }}$ (Transduction Laboratories, UK) were employed to assess expression of these NADPH oxidase subunits. Protein bands were detected by the ECL system (Amersham, UK) and visualised by autoradiography. Blots were quantified by densitometry.

\section{Lucigenin-enhanced chemiluminescence}

Production of $\mathrm{O}_{2}^{-}$was measured by lucigeninenhanced chemiluminescence according to previously described and validated methods. ${ }^{15-16}$ In brief, frozen LV samples from each mouse strain ( $n \geq 5$ per group) were homogenized in lysis buffer containing protease inhibitors (1:20, protease cocktail), monobasic potassium phosphate $(20 \mathrm{mmol} / \mathrm{L})$ and EGTA ( $1 \mathrm{mmol} / \mathrm{L})$, pH 7.0. For each sample, tissue homogenate containing $100 \mu \mathrm{g}$ was added to wells, on a 96-well microplate luminometer (Lucy 1, Rosys Anthos, Austria). The assay buffer comprised of (in mmol/L); sucrose 150, monobasic potassium phosphate 50, and EGTA 1 . Immediately before measurement of chemiluminescence, NADPH ( $300 \mu \mathrm{mol} / \mathrm{L}, \mathrm{pH} 7.0)$ was added to each well, followed by dark-adapted lucigenin $(5 \mu \mathrm{mol} / \mathrm{L})$. Chemiluminescence was recorded every minute for $25 \mathrm{~min}$. In some experiments, the cell-permeable $\mathrm{O}_{2}^{-} \quad$ scavenger 4,5-dihydroxy-1, 3-benzenedisulfonic acid disodium (Tiron, $20 \mathrm{mmol} / \mathrm{L}$ ), the NOS inhibitor, N $\omega$-nitro-L-arginine methyl ester hydrochloride (L-NAME, $100 \mu \mathrm{mol} / \mathrm{L}$ ), or a flavoprotein inhibitor diphenyleneiodonium (DPI, $10 \mu \mathrm{mol} / \mathrm{L}$ ) were incubated with the homogenate for $5 \mathrm{~min}$ before addition of NADPH and lucigenin. A buffer blank ( $<2 \%$ of the homogenate signal) was subtracted from each reading before analysis of the data.

$\mathrm{NADPH}$-driven $\mathrm{O}_{2}^{-}$production was also measured in aortic homogenates from MF1 and C57BL/6J mice according to the protocol described above with slight modifications; aortae were homogenised ( $10 \%$ weight for volume in lysis buffer) using a glass-glass homogeniser and $10 \mu \mathrm{l}$ of homogenate was added to each well.

\section{Drugs and chemicals}

$\mathrm{N}^{\mathrm{G}}$-monomethyl-L-arginine was obtained from Calbiochem (UK); N $\omega$ (-nitro-L-arginine methyl ester hydrochloride, diphenyleneiodium chloride, 4,5-dihydroxy-1,3-benzene-disulfonic acid disodium, NADPH, lucigenin, bradykinin, acetylcholine chloride, adenosine, sodium nitroprusside, L-phenylephrine hydrochloride, calcium ionophore A23187 and protease cocktail from Sigma-Aldrich (UK); and all other chemicals from Merck (BDH) and Laboratory Supplies (UK) unless otherwise stated in the text. All drugs were freshly prepared on the day of the experiment in de-ionised water, except for A23187 which was dissolved in dimethyl sulphoxide (DMSO). DMSO had no effect on vessel function alone at the maximal concentration $(0.01 \%)$ used in the isolated aortic rings.

\section{Statistics}

Data are presented as mean values \pm SEM. Doseresponse curves for coronary vasodilator responses and curves for $\mathrm{O}_{2}^{-}$production were compared by two-way ANOVA for repeated measures followed by the Fischer's Least Significance post-hoc test. Other data were compared by one-way ANOVA followed by Fischer's Least Significance post-hoc test or by the Student's unpaired $t$-test. $P<0.05$ was considered significant.

\section{Results}

Baseline characteristics

Heart weights were similar in all three murine strains (C57BL/6J, $149 \pm 9 \mathrm{mg}$; 129sv, $144 \pm 6 \mathrm{mg}$; $\mathrm{MF} 1,149 \pm 9 \mathrm{mg})$. However, at the same CPP of 
$60 \mathrm{mmHg}$, baseline coronary flow in C57BL/6J and $129 \mathrm{sv}$ hearts was significantly lower than in MF1 hearts $(0.009, \quad 0.012$ and $0.017 \mathrm{ml} / \mathrm{min} / \mathrm{mg}$ respectively, $P<0.001)$. Consequently, mean coronary vascular resistance was significantly higher in $\mathrm{C} 57 \mathrm{BL} / 6 \mathrm{~J}$ hearts $(43.13 \pm 3.42 \mathrm{mmHg} / \mathrm{ml} / \mathrm{min})$ compared with MF1 hearts $(25.61 \pm 1.63 \mathrm{mmHg}$ / $\mathrm{ml} / \mathrm{min}, P<0.001$ ), with $129 \mathrm{sv}$ hearts being at an intermediate level $(33.92 \pm 4.81 \mathrm{mmHg} / \mathrm{ml} / \mathrm{min})$.

\section{Coronary vasomotor responses}

Bradykinin induced significantly greater relaxation in C57BL/6J and 129sv hearts compared with MF1 mice [Fig. 1(A)]. Maximal relaxation to bradykinin was $29.4 \pm 5.5 \%$ and $31.4 \pm 5.2 \%$ in $129 \mathrm{sv}$ and C57BL/6J hearts respectively compared with only $11.5 \pm 2.6 \%$ for MF1 hearts $(P<0.01)$.

Relaxation to ACh was also markedly different between the three murine strains. Maximal relaxation to ACh was greatest in C57BL/6J hearts $(38.8 \pm 5.7 \%)$ followed by $129 \mathrm{sv}(25.5 \pm 7.7 \%)$ and MF1 ( $4.9 \pm 1.4 \%)$ hearts $[P<0.01$, Fig. $1(\mathrm{~B})]$.

In line with these results, coronary relaxation to SNP was also significantly different between the groups. Relaxation in 129sv hearts was significantly greater than in MF1 hearts [Fig. 1(C)]. Relaxation in $\mathrm{C} 57 \mathrm{BL} / 6 \mathrm{~J}$ hearts tended to be greater but did not reach significance.

Similarly, maximal vasodilator responses to adenosine were markedly attenuated in MF1 hearts compared with $129 \mathrm{sv}$ and C57BL/6J mice [Fig. 2(A); $P<0.01]$. L-NMMA increased CPP in hearts in all strains. However, the maximal response was significantly lower in MF1 and 129sv hearts compared with C57BL/6J hearts [Fig. 2(B); $P<0.01$ ].

\section{Aortic relaxation}

To eliminate potential confounding factors such as coronary vascular resistance and coronary flow, vascular relaxation was also assessed in aortic rings. In addition, the lack of a preload in the isolated heart preparation could influence vasorelaxation therefore it was important to establish if the differences were maintained in isolated precontracted aortae. Contraction dose-response curves to PE were not significantly different between C57BL/6J and MF1 mouse aortic rings (maximum tension; $1.75 \pm 0.23$ and $1.31 \pm 0.11 \mathrm{~g} / \mathrm{mg}$ respectively). However, in line with the results seen in the whole heart, the endothelium-dependent agonist ACh produced a significantly greater maximum
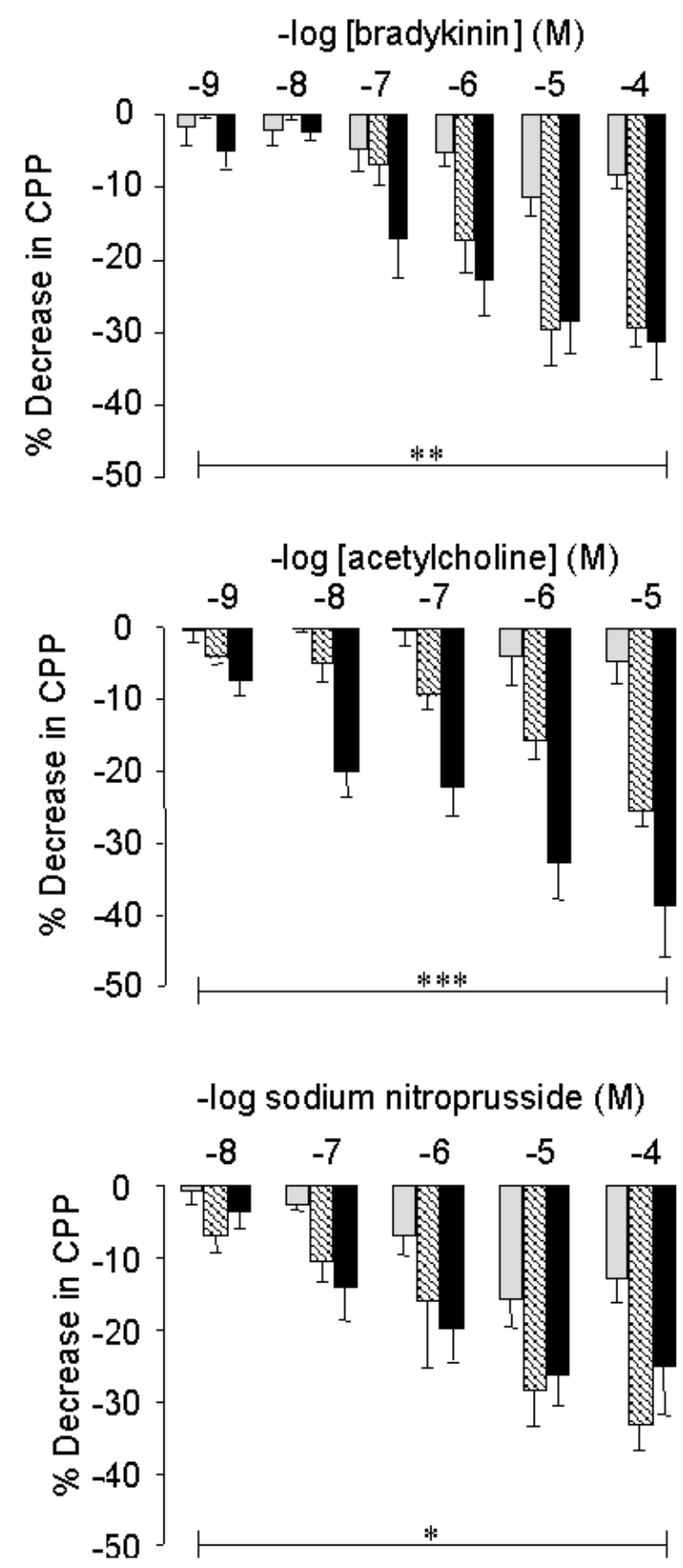

Figure 1 Coronary vascular relaxation to endotheliumdependent and -independent vasoactive agents. Percentage changes in CPP of isolated hearts from MF1 $(\square)$, $129 \mathrm{sv}(\mathbb{\nabla})$ and C57BL/6J ( $)$ mice in response to increasing doses of (A) bradykinin $(1 \mathrm{nmol} / \mathrm{L}-0.1 \mathrm{mmol} / \mathrm{L})$; (B) ACh $(1 \mathrm{nmol} / \mathrm{L}-10 \mu \mathrm{mol} / \mathrm{L})$; and $(\mathrm{C}) \mathrm{SNP}(10 \mathrm{nmol} / \mathrm{L}-$ $0.1 \mathrm{mmol} / \mathrm{L})$. ${ }^{*} \mathrm{P}<0.05$; ${ }^{* *} \mathrm{P}<0.01$; ${ }^{* * *} \mathrm{P}<0.001$.

relaxation in C57BL/6J aortic rings compared with MF1 rings $(85 \pm 9.6$ and $57 \pm 9.1 \%$ respectively, $P<0.05$, Fig. 3(A)). Relaxations to ACh were improved in the presence of Tiron in MF1 aortae but remained unchanged in $\mathrm{C} 57 \mathrm{BL} / 6 \mathrm{~J}$ mice 
[Fig. 3(B)]. Maximal relaxation in response to the calcium ionophore A23187 and SNP was, however, similar between MF1 and C57BL/6J mice [Figs 3(C) and (D)].

\section{Expression of eNOS and NADPH oxidase subunits}

The level of eNOS protein expression was significantly reduced in $\mathrm{C} 57 \mathrm{BL} / 6 \mathrm{~J}$ hearts when compared with the MF1 strain $[P<0.05$, Figs $4(\mathrm{~A})$ and (B)].
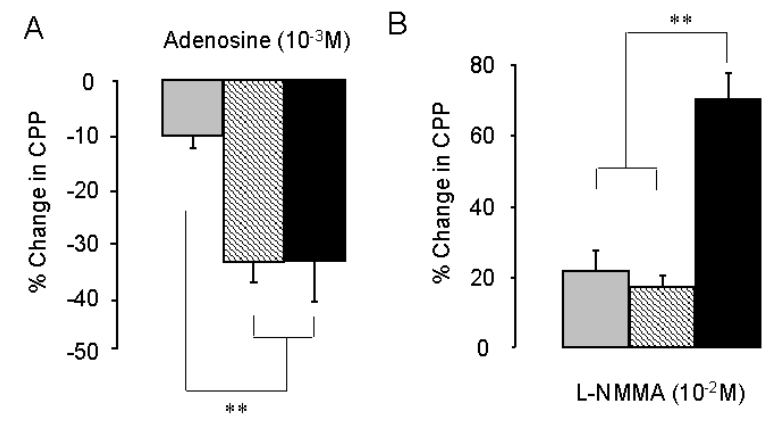

Figure 2 Coronary vascular responses to adenosine and L-NMMA. Percentage change in CPP of isolated hearts from MF1 $(\square), 129 \mathrm{sv}(\mathbb{Q})$ and C57BL/6J ( $\square$ ) mice in response to (A) adenosine ( $1 \mathrm{mmol} / \mathrm{L})$; and (B) L-NMMA (0.1 mmol/L). **, $P<0.01$.
Significant differences were also seen in the expression level of 2 subunits of the NADPH oxidase complex, namely gp91 ${ }^{\text {phox }}$ (a component of the membrane bound cytochrome $b_{558}$, thought to be responsible for $\mathrm{O}_{2}^{-}$generation) and $\mathrm{p} 67^{\text {phox }}$ (a regulatory subunit). C57BL/6J hearts expressed significantly reduced amounts of gp9 $1^{\text {phox }}$ compared with MF1 and $129 \mathrm{sv}$ hearts $[P<0.05$, Figs $4(\mathrm{~A})$ and (B)]. In addition, p6 $67^{\text {phox }}$ protein expression was significantly decreased in both C57BL/6J and $129 \mathrm{sv}$ hearts compared with the MF1 strain $[P<0.05$, Figs $4(A)$ and $(B)]$.

\section{NADPH-driven superoxide production}

Consistent with the differences observed in NADPH oxidase subunit expression, NADPH-driven $\mathrm{O}_{2}^{-}$ production was significantly depressed in LV homogenates from $\mathrm{C} 57 \mathrm{BL} / 6 \mathrm{~J}$ and $129 \mathrm{sv}$ strains compared with MF1 mice [Fig. 5(A)]. Importantly, LV $\mathrm{O}_{2}^{-}$production was virtually abolished by the NADPH oxidase flavoprotein inhibitor, DPI and the $\mathrm{O}_{2}^{-}$scavenger, Tiron, but was unaffected by the NOS inhibitor, L-NAME in all three groups [Fig. 5(B)]. In line with these results, NADPH-driven $\mathrm{O}_{2}^{-}$production was also significantly increased in aortae from MF1 mice compared with C57BL/6J
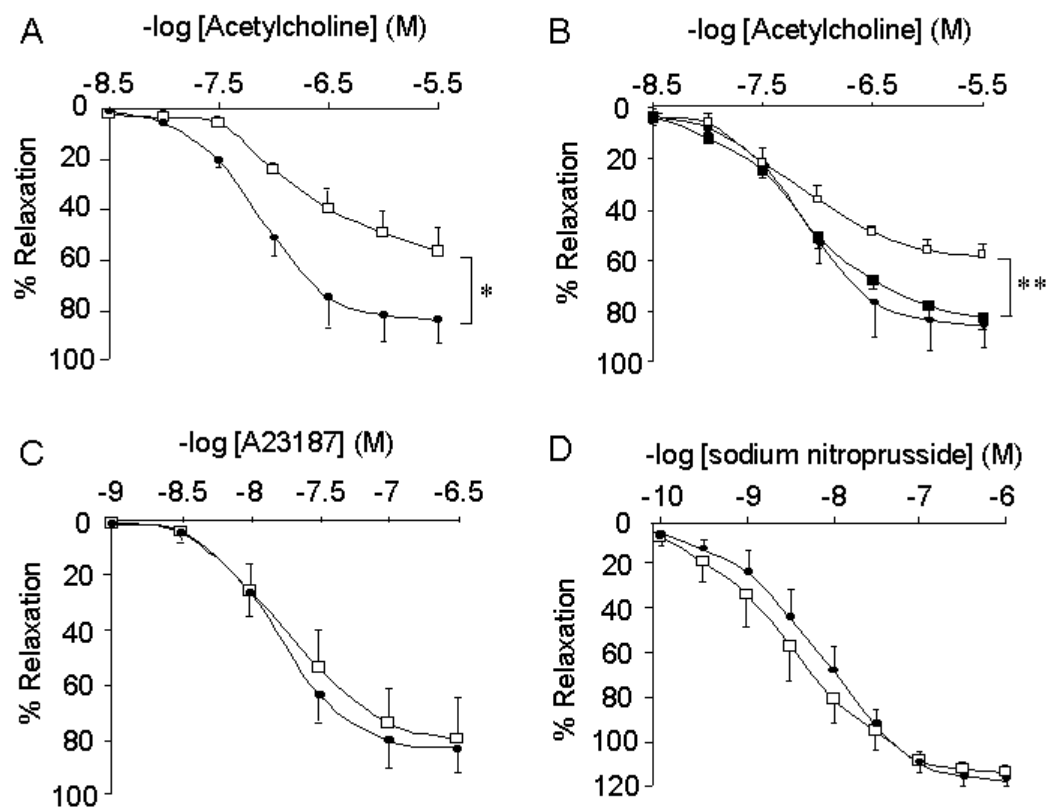

Figure 3 Aortic relaxation to endothelium-dependent and -independent vasoactive agents. Percentage relaxation of aortic rings in response to cumulative doses of (A) ACh $(3 \mathrm{nmol} / \mathrm{L}-3 \mu \mathrm{mol} / \mathrm{L})$ in MF1 ( $\square$ ) and C57BL/6J (O) mice; (B) ACh $(3 \mathrm{nmol} / \mathrm{L}-3 \mu \mathrm{mol} / \mathrm{L})$ in MF1 mice in the presence $(\square)$ or absence $(\square)$ of Tiron $(5 \mathrm{mmol} / \mathrm{L})$ and in C57BL/6J mice in the absence of Tiron (O); (C) the calcium ionophore A23187 (1 nmol/L-0.3 $\mu \mathrm{mol} / \mathrm{L})$ in MF1 ( $\square)$ and C57BL/6J (O) mice; and (D) SNP $(0.1 \mathrm{nmol} / \mathrm{L}-1 \mu \mathrm{mol} / \mathrm{L})$ in MF1 $(\square)$ and C57BL/6J (O) mice. ${ }^{*} P<0.05$ and ${ }^{* *} P<0.01$ for MF1 with respect to $\mathrm{MF} 1$ in the presence of Tiron. 

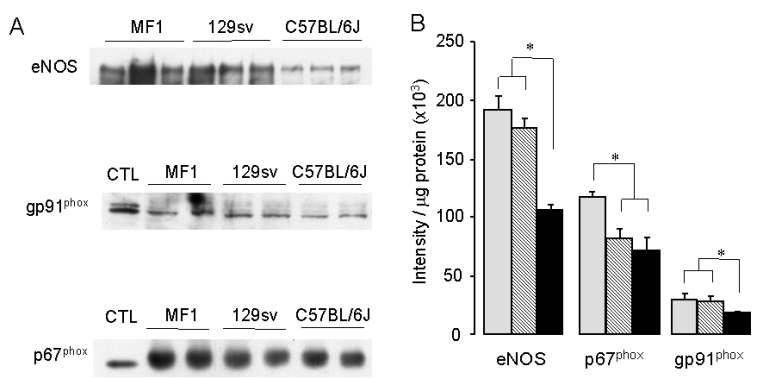

Figure 4 Protein expression of eNOS and NADPH oxidase subunits. Protein expression of eNOS and the NADPH oxidase subunits, gp9 $1^{\text {phox }}$ and $\mathrm{p} 67^{\text {phox }}$, in murine hearts. (A) representative Western blots and (B) densitometric comparison of expression levels. MF1 ( $\square$ ), $129 \mathrm{sv}$ ) and C57BL/6J ( $\mathbf{\square})$. For a positive control (CTL) U937 cells were used. ${ }^{*} P<0.05$.

[Fig. 5(C)]. Again, DPI and Tiron abolished the chemiluminescence signal whereas L-NAME had no significant effect (data not shown).

\section{Discussion}

The present study demonstrates that marked murine strain-dependent differences exist in terms of (a) baseline coronary vascular resistance; (b) vasodilator responses to endothelium-dependent agonists; (c) maximal coronary vasodilator capacity in response to adenosine; (d) basal coronary NO bioactivity; (e) LV protein expression of eNOS and NADPH oxidase; and (f) LV NADPHdriven $\mathrm{O}_{2}^{-}$production.

Vascular tone is regulated by a large number of factors, including NO, prostacyclin, endotheliumderived hyperpolarizing factor(s) (EDHF), endothelin, and $\mathrm{O}_{2}^{-} \cdot{ }^{17}$ This is one of the first studies to investigate strain-dependent differences in coronary vascular tone in the isolated murine heart. Importantly, Chaitagneau et al. ${ }^{18}$ demonstrated that endothelium-dependent relaxations to ACh in aortae and left descending coronary arteries of C57BL/ $6 \mathrm{~J}$ mice were completely abolished by inhibition of NOS or by gene-targeted deletion of eNOS (eNOSdeficient mice), indicating that in these vessels NO is the main contributor to the response to ACh. However, in contrast, in the integrated coronary bed Godecke et al. ${ }^{7,19}$ demonstrated that, whilst responses to bradykinin are predominantly NOmediated, ${ }^{19-20}$ responses to ACh have a significant prostacyclin-dependent component. EDHF did not appear to contribute to coronary relaxation in response to these endothelium-dependent vasodilators.
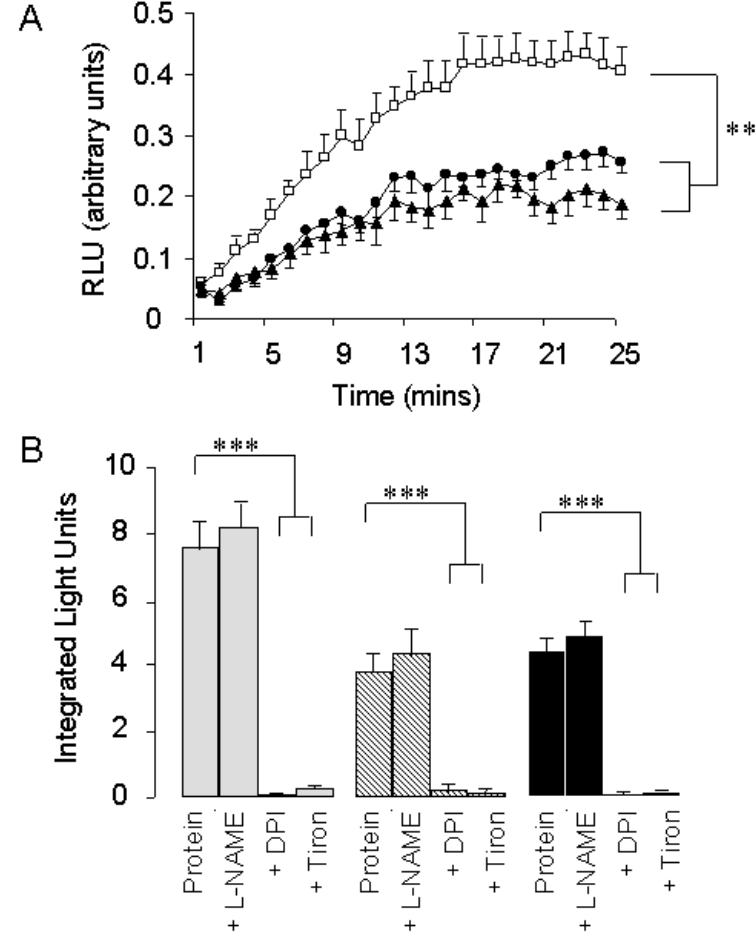

C

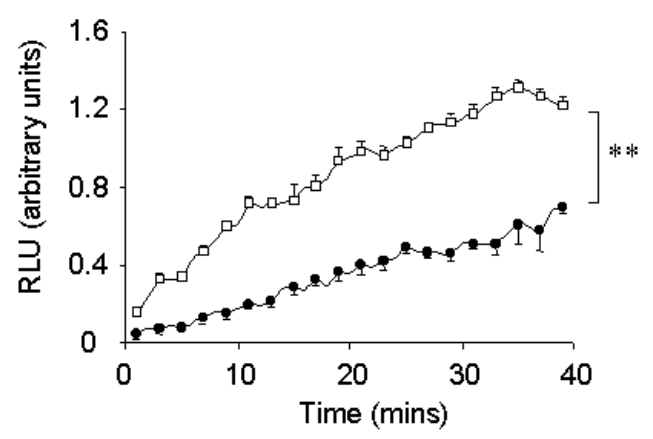

Figure 5 NADPH-dependent superoxide production. $\mathrm{NADPH}$-driven $\mathrm{O}_{2}^{-}$production measured by lucigenin ( $5 \mu \mathrm{mol} / \mathrm{L}$ )-enhanced chemiluminescence. (A) LV homogenates from MF1 $(\square), 129 \mathrm{sv}(\mathbf{\Delta})$ and $\mathrm{C} 57 \mathrm{BL} / 6 \mathrm{~J}(\boldsymbol{\bullet}$ mice measured over $25 \mathrm{~min}$. (B) LV homogenates from MF1 ( $\square$ ), 129sv ( $\square$ ) and C57BL/6J mice ( $(\mathbf{a})$ in the presence of the NOS inhibitor (L-NAME), the NADPH oxidase flavoprotein inhibitor (DPI), or the $\mathrm{O}_{2}^{-}$scavenger, Tiron (measured as integrated $\mathrm{O}_{2}^{-}$production, area under the curve). (C) Aortic homogenates from MF1 ( $\square$ ) and $\mathrm{C} 57 \mathrm{BL} / 6 \mathrm{~J}(-)$ mice measured over $40 \mathrm{~min}$. $\mathrm{RLU}=$ relative light units. ${ }^{* *} P<0.01,{ }^{* * *} P<0.001$.

In the present study, coronary vasodilator responses to both endothelium-dependent vasoactive agents, ACh and bradykinin, differed significantly between the strains with the MF1 hearts consistently responding poorly. Maximal coronary vasodilator responses to the endothelium-independent agonist, SNP also differed among the strains. However, the differences were less marked due 
mainly to improved relaxation in the MF1 hearts. These results suggest therefore that the observed differences in coronary vascular relaxation may reflect differences in both the endothelial response to the agonists and the coronary vascular response to NO per se. Differences in the response of the two inbred strains to ACh could also reflect differences in receptor density, the signal transduction pathway or the relative contributions of potential vasodilator agents other than NO, such as prostacyclins and EDHF. Interpretation of the data is however complicated by the fact that $\mathrm{C} 57 \mathrm{BL} / 6 \mathrm{~J}$ isolated mouse hearts had a greater basal coronary vascular resistance compared with MF1 hearts, with 129 sv hearts being at an intermediate value. Consistent with the lower basal resistance, the maximal response to adenosine (as an index of the maximal coronary dilator capacity $)^{21}$ was significantly lower in MF1 hearts compared with the other two strains. The underlying causes of the variation in basal coronary vascular resistances in the isolated heart preparations were not studied. However, factors other than NO such as leukotrienes, thromboxane, endothelin and angiotensin II may play a role in increasing vascular tone in $\mathrm{C} 57 \mathrm{BL} / 6 \mathrm{~J}$ mice.

In order to completely eliminate the confounding effects of coronary flow, basal vascular resistance and the absence of a preload in the isolated heart preparation and to compare relaxation between different vascular beds, aortic ring experiments were conducted. In line with the isolated heart data, vascular responses to the endothelium-dependent agonist, $\mathrm{ACh}$, were significantly greater in $\mathrm{C} 57 \mathrm{BL} /$ 6J rings compared with the MF1 strain. The $\mathrm{O}_{2}^{-}$ scavenger, Tiron, significantly improved vascular relaxations in MF1 mice but had no effect in C57BL/6J animals. The observation that Tiron restored responses in the MF1 strain so that they resembled those obtained in $\mathrm{C} 57 \mathrm{BL} / 6 \mathrm{~J}$ aortae suggests that the impaired responses in this strain may be due to increased scavenging of bioavailable NO by $\mathrm{O}_{2}^{-}$. These data highlight the fact that, irrespective of vascular resistance, $\mathrm{C} 57 \mathrm{BL} / 6 \mathrm{~J}$ vessels demonstrate a markedly increased response to endothelium-derived NO compared with the other strains. However, responses to the endotheliumdependent, receptor-independent NO agonist, A23187, and the endothelium-independent NO agonist, SNP, were not different. In the aorta, therefore, differences in vascular responsiveness and sensitivity may be due mainly to an increased inactivation of endothelial-derived $\mathrm{NO}$ by $\mathrm{O}_{2}^{-}$.

The vascular response to $\mathrm{NO}$ is known to be influenced by several factors, including the level of eNOS protein expression, the amount of NO released, inactivation of NO by reactive oxygen species, and vascular smooth muscle responsiveness per se. ${ }^{22}$ Western blot analysis demonstrated paradoxically that, although $\mathrm{C} 57 \mathrm{BL} / 6 \mathrm{~J}$ hearts were most sensitive to both ACh and bradykinin, eNOS protein expression was least in these hearts. On the other hand, basal NO bioactivity, as estimated by NO synthase inhibition, was highest in the C57BL/ 6J strain and lowest in the MF1 strain. These conflicting data may be explained by the upregulation of other NOS isoforms in C57BL/6 J mice. However, since NO-dependent vascular effects reflect the balance between NO production and inactivation, ${ }^{23}$ we assessed NADPH oxidase expression and activity in these hearts. The phagocyte-type NADPH oxidase complex is now considered to be a major source of $\mathrm{O}_{2}^{-}$in endothelium, vascular smooth muscle, adventitial fibroblasts and cardiac myocytes, ${ }^{2,24,25}$ and several studies have now demonstrated that $\mathrm{O}_{2}^{-}$generated from this oxidase influences vascular tone both in vitro and in vivo. ${ }^{26-28}$ Importantly, C57BL/6J hearts expressed lower protein levels of the NADPH oxidase subunits, gp91 ${ }^{\text {phox }}$ and p6 $7^{\text {phox }}$, and MF1 hearts the highest. We also found that NADPH-dependent $\mathrm{O}_{2}^{-}$generation in MF1 LV homogenate and aortae was significantly higher than observed for C57BL/6J and $129 \mathrm{sv}$ strains. In line with the suggestion that the $\mathrm{O}_{2}^{-}$ generated in these tissues is derived from the $\mathrm{NADPH}$ oxidase, chemiluminescence was completely inhibited by the flavoprotein inhibitor, DPI, but not by the NOS inhibitor, L-NAME. The fact that Tiron could restore ACh-induced vasorelaxation in MF1 aortae to that obtained in C57BL/6J animals suggests that such an upregulation of NADPH oxidase activity plays an important role in the control of vascular smooth muscle tone. However further experiments are required before this conclusion could be extended to the coronary vasculature.

In summary, this study demonstrates that there are marked strain-dependent differences in murine coronary vascular function and highlights the importance of characterizing baseline physiology prior to interpretation of potential differences induced by genetic manipulation. Differences in coronary vascular sensitivity to ACh, bradykinin and SNP and basal coronary vascular tone may reflect variations in the relative balance between $\mathrm{NO}$ and $\mathrm{O}_{2}^{-}$production and degradation. Since a hallmark of many cardiovascular pathologies, including hypertension, hypertrophy and heart failure, is altered production of reactive oxygen species, baseline differences in these parameters will undoubtedly influence the development of such pathologies in transgenic murine models of disease. 


\section{Acknowledgements}

This work was supported financially by the Joint Research Committee of King's Healthcare NHS Trust, and the British Heart Foundation. AMS holds the BHF Chair of Cardiology at King's College London.

\section{References}

1. Kass DA, Hare JM, Georgakopoulos D. Murine cardiac function. A cautionary tail. Circ Res 1998; 82: $519-522$

2. Gorlach A, Brandes RP, Nguyen K, Amidi M, DeHghani F, Busse R. A gp91 $1^{\text {phox }}$ containing NADPH oxidase selectively expressed in endothelial cells is a major source of oxygen radical generation in the arterial wall. Circ Res 2000; 87: 26-32.

3. Akishita, M, Yamada H, Dzau VJ, Horiuchi M. Increased vasoconstrictor response of the mouse lacking angiotensin II type 2 receptor. Biochem Biophys Res Commun 1999; 261: 345-349.

4. FARACI FM, Sigmund CD. Vascular biology in genetically altered mice. Smaller vessels, bigger insight. Circ Res 1999; 85: 1214-1225.

5. Duplain H, Burcelin R, Sartori C, Cook S, Egli M, Lepori M, Vollenweider P, Pedrazzini T, Nicod P, THORENS B, SCHERRER U. Insulin resistance, hyperlipidemia, and hypertension in mice lacking endothelial nitric oxide synthase. Circulation 2001; 104: 342-345.

6. Scotland RS, Chauhan S, Vallance PJT, Ahluwalia A. An endothelium-derived hyperpolarizing factorlike factor moderates myogenic constriction of mesenteric resistance arteries in the absence of endothelial nitric oxide synthase-derived nitric oxide. Hypertension 2001; 38: 833-839.

7. Godecke A, Decking UKM, Ding Z, Hirchenhain J, Bidmon H-J, Godecke S, Schrader J. Coronary hemodynamics in endothelial NO synthase knockout mice. Circ Res 1998; 82: 186-194.

8. Abe H, Yamada N, Kamata K, Kuwaki T, Shimada M, Osuga J, Shionoiri F, Yahagi N, Kadowaki T, TAMEMoto $\mathrm{H}$, Ishibashi S, YazaKi $\mathrm{Y}$, MaKuUChI $\mathrm{M}$. Hypertension, hypertriglyceridemia, and impaired endothelium-dependent vascular relaxation in mice lacking insulin receptor substrate-1. J Clin Invest 1998; 101: 1784-1788.

9. Russell A, WatTs S. Vascular reactivity of isolated thoracic aorta of the C57BL/6J mouse. J Pharmacol Exp Ther 2000; 294: 598-604.

10. WeIler H, Lindner V, Kerlin B, Isermann BH, HendRICKSON SB, COOLEy BC, MeH DA, MosesSON MW, Shworak NW, Post MJ, Conway EM, Ulfman LH, von ANDRIAN UH, WeITZ JI. Characterization of a mouse model for thrombomodulin deficiency. Arterioscler Throm Vasc Biol 2001; 21: 1531-1537.

11. Tada H, Thompson CI, Recchia FA, Loke KE, OchoA M, Smith CJ, Shesely EG, Kaley G, Hintze TH. Myocardial glucose uptake is regulated by nitric oxide via endothelial nitric oxide synthase in Langendorff mouse heart. Circ Res 2000; 86: 270-274.

12. Milia AF, Gross V, Plehm R, De Silva JaJ, Bader M, LuFT FC. Normal blood pressure and renal function in mice lacking the bradykinin B2 receptor. Hypertension 2001; 37: 1473-1479.

13. LIJNen HR, Soloway P, Collen D. Tissue inhibitor of matrix metalloproteinases-1 impairs arterial neointima formation after vascular injury in mice. Circ Res 1999; 85: 1186-1191.

14. BRADFORD MM. A rapid and sensitive method for the quantitation of microgram quantities of protein utilizing the principle of protein-dye binding. Anal Biochem 1976; 72: 248-254.

15. Griendling KK, Minieri CA, Ollerenshaw JD, ALEXANDER RW. Angiotensin II stimulates $\mathrm{NADH}$ and NADPH oxidase activity in cultured vascular smooth muscle cells. Circ Res 1994; 74: $1141-1148$.

16. Li Y, Zhu H, Kuppusamy P, Roubaud V, Zweier JL, TRusH MA. Validation of lucigenin (Bis-N-methylacridinium) as a chemilumigenic probe for detecting superoxide anion radical production by enzymatic and cellular systems. J Biol Chem 1998; 273: 2015-2023.

17. Busse R, Trogisch G, Bassenge E. The role of the endothelium in the control of vascular tone. Basic Res Cardiol 1985; 80: 475-490.

18. Chataigneau T, Feletou M, Huang PL, Fishman MC Duhault J, Vanhoutte PM. Acetylcholine-induced relaxation in blood vessels from endothelial nitric oxide synthase knockout mice. $\mathrm{Br} J$ Pharmacol 1999; 126: 129-226.

19. Godecke A, Ziegler M, Ding Z, Schrader J. Endothelial dysfunction of coronary resistance vessels in apoE/ mice involves NO but not prostacyclin-dependent mechanisms. Cardiovasc Res 2002; 53: 253-262.

20. LoKe KE, Mcconnell PI, Tuzman JM, Shesely EG, Smith CJ, Stackpole CJ, Thompson CI, Kaley G, WoLIN MS, HINTZE TH. Endogenous endothelial nitric oxide synthase-derived nitric oxide is a physiological regulator of myocardial oxygen consumption. Circ Res 1999; 84: 840-845.

21. Erga KS, Seubert CN, Liang H-X, Wu L, Shryock JC, BELARDINELLI L. Role of $\mathrm{A}_{2 \mathrm{~A}}$-adenosine receptor activation for ATP-mediated coronary vasodilation in guinea-pig isolated heart. $\mathrm{Br} J$ Pharmacol 2000; 130: 1065-1075.

22. SHAH AM, Maccarthy PA. Paracrine and autocrine effects of nitric oxide on myocardial function Pharmacology and Therapeutics 2000; 86: 49-86.

23. Gryglewski RJ, Palmer RM, Moncada S. Superoxide anion is involved in the breakdown of endotheliumderived vascular relaxing factor. Nature 1986; 320: 454-456.

24. MoHAZZAв-H KM, Kaminski PM, Wolin MS. NADH oxidoreductase is a major source of superoxide anion in bovine coronary artery endothelium. Am J Physiol 1994; 266: H2568-H2572.

25. Bayraktutan U, Draper N, Lang D, Shah AM. Expression of a functional neutrophil-type NADPH oxidase in cultured rat coronary microvascular endothelial cells. Cardiovasc Res 1998; 38: 256-262. 
26. Griending KK, Sorescu D, Ushio-Fukai M. NAD(P)H oxidase. Role in cardiovascular biology and disease. Circ Res 2000; 86: 494-501.

27. Fukai T, SiEgFried MR, Ushio-FuKai M, GRIENDLING KK, HARRISON DG. Modulation of extracellular superoxide dismutase expression by angiotensin II and hypertension. Circ Res 1999; 85: 23-28.
28. Wang HD, Hope S, Du Y, Quinn MT, CAYetTe A, Pagano PJ, Cohen RA. Paracrine role of adventitial superoxide anion in mediating spontaneous tone of the isolated rat aorta in angiotensin IIinduced hypertension. Hypertension 1999; 33: 1225-1232. 